Article

\title{
Reduced Dendritic Cells Expressing CD200R1 in Children with Inflammatory Bowel Disease: Correlation with Th17 and Regulatory T Cells
}

\author{
Mohamed F. Elshal 1,2,3,*, Alia M. Aldahlawi ${ }^{2,4,5}$, Omar I. Saadah ${ }^{2,6}$ and J. Philip McCoy 2,7 \\ Received: 12 October 2015; Accepted: 26 November 2015; Published: 4 December 2015 \\ Academic Editor: Kamal D. Moudgil \\ 1 Biochemistry Department, Faculty of Sciences, King Abdulaziz University, Jeddah 21589, Saudi Arabia \\ 2 Inflammatory Bowel Disease Research Group, King Abdulaziz University, Jeddah 21589, Saudi Arabia; \\ alia008@hotmail.com (A.M.A.); osaadah@kau.edu.sa (O.I.S.); mccoyj@nhlbi.nih.gov (J.P.M.) \\ 3 Molecular Biology Department, Genetic Engineering and Biotechnology Research Institute, Sadat City \\ University, Sadat City 32897, Egypt \\ 4 Biological Sciences Department, Faculty of Sciences, King Abdulaziz University, Jeddah 21589, \\ Saudi Arabia \\ 5 Immunology Unit, King Fahd Medical Research Center, King Abdulaziz University, Jeddah 21589, \\ Saudi Arabia \\ 6 Department of Pediatrics, Faculty of Medicine, King Abdulaziz University, Jeddah 21589, Saudi Arabia \\ 7 Flow Cytometry Core Facility, National Heart, Lung, and Blood Institute, National Institutes of Health, \\ Bethesda, MD 20892, USA \\ * Correspondence: melshal@kau.edu.sa; Tel.: +966-542-028-446
}

\begin{abstract}
Loss of tolerance of the adaptive immune system towards indigenous flora contributes to the development of inflammatory bowel diseases (IBD). Defects in dendritic cell (DC)-mediated innate and adoptive immune responses are conceivable. The aim of this study was to investigate the expression of the inhibitory molecules CD200R1 and their ligand CD200 on DCs, to clarify the role of the DCs in the pathogenesis of IBD. Thirty-seven pediatric IBD patients (23 with Crohn's disease (CD) and 14 with ulcerative colitis (UC)) with mean age $13.25 \pm 2.9$ years were included. Fourteen age-matched healthy pediatric volunteers (five males and nine females) served as a control group (HC). The percentage of $\mathrm{CD} 11 \mathrm{c}^{+}$myeloid dendritic cells (mDCs) and $\mathrm{CD}_{123^{+}}$ plasmacytoid DCs (pDCs) expressing CD200R1 and CD200 were evaluated in peripheral blood using flow cytometry and were correlated with routine biochemical, serological markers, serum levels of cytokines and with the percentages of circulating regulatory $\mathrm{T}$ cells (Treg) and $\mathrm{CD} 4^{+}$ producing IL-17 (Th17). IBD patients showed a significant decrease in the percentage of pDCs and mDCs expressing CD200R1 compared to that of HC. Patients with UC showed increased expressions of the CD200 molecule on pDCs as compared to HC. DCs expressing CD200R1 were found to be correlated positively with Treg and negatively with TH17 and erythrocyte sedimentation rate (ESR). Our findings suggest that IBD is associated with dysregulation in the CD200R1/CD200 axis and that the decrease in DCs expressing CD200R1 may contribute to the imbalance of Th17 and Treg cells and in the pathogenesis of IBD.
\end{abstract}

Keywords: inflammatory bowel disease; ulcerative colitis; Crohn's disease; plasmacytoid dendritic cells; myeloid dendritic cells; CD200R1; CD200; TH17 and regulatory T cells

\section{Introduction}

Inflammatory bowel diseases (IBD) are chronic autoimmune diseases that affect the small bowel and/or the colon and are comprised mainly of Crohn's disease (CD) and ulcerative colitis (UC) [1]. 
Recent epidemiological studies suggest an increase in the incidence of pediatric IBD, with about $10 \%$ of cases with IBD occurring in children less than 10 years old [2-4]. Several risk factors have been associated with these epidemiologic changes, including excessive use of antibiotics [5], shifts towards a more Westernized high fat, a high carbohydrate diet and urbanization [6]. It has been suggested that these factors alter the composition of the intestinal microflora and induce exaggerated inflammatory responses to these alterations in genetically-susceptible hosts $[7,8]$. These bacterial changes may result in the disturbance of immune tolerance and cause immune alterations, such as secreting inflammatory mediators, recruiting dendritic cells (DCs) and presenting antigens to $\mathrm{T}$ helper $\left(\mathrm{CD} 4^{+}\right)$lymphocytes $[9,10]$.

DCs are a special subset of antigen-presenting cells (APCs) that are widely distributed in all peripheral tissues, including the intestinal mucosa. In the presence of infection or inflammation, DCs have the capacity to capture antigens, migrate to lymph nodes and prime naive $\mathrm{T}$ cells, therefore functioning as initiators of T-cell immunity. On the other hand, under steady-state conditions, DCs induce peripheral T-cell tolerance [11]. Substantial evidence indicates that DCs mediate $\mathrm{T}$ cell unresponsiveness through induction of tryptophan catabolism mediated by indoleamine 2,3-dioxygenase (IDO) [12]. Depletion of tryptophan has significant effects on T lymphocytes, leading to their anergy and apoptosis $[13,14]$. Fallarino et al. [12] found that induction of IDO depends on the engagement of CD200 with its receptor CD200R1 on the surface of DCs.

CD200 is a type I transmembrane glycoprotein that binds to its receptor CD200R1 on macrophages and dendritic cells, resulting in the regulation of inflammatory immune responses, cytokine production and maintenance of immune homeostasis [15]. In addition, Gorczynski et al. [16] demonstrated that the interaction between CD200 and CD200R1 was implicated in the development of tolerogenic DCs that preferentially induce populations of $\mathrm{CD} 4{ }^{+} \mathrm{CD} 25^{+}$regulatory $\mathrm{T}$ cells (Treg) capable of dampening or preventing immune responses. Treg cells are especially important in the intestine, where the mucosa is exposed to a wide range of foreign antigens, including indigenous flora and dietary antigens [17]. Defects in the number or function of Treg was found to be associated with a breakdown in intestinal tolerance that may contribute to the development of IBD [18].

Blocking the interaction of CD200R1 with its ligand was found to activate DCs and promotes T helper-17 (Th17) differentiation [19]. Recently, it has been found that elevated levels of IL-17 may contribute to the pathogenesis of IBD [20].

CD200/CD200R1 signaling has been suggested to play a role in the induction of autoimmune diseases. In rodents, blocking CD200/CD200R1 binding was found to aggravate the clinical course of experimental autoimmune diseases [21,22]. Consistent with this premise, dysfunction in CD200/CD200R1 signaling has been reported in numerous autoimmune diseases, including Parkinson's disease [23], Alzheimer's disease [24], rheumatoid arthritis [25], uveoretinitis [26], lupus [27], autoimmune and inflammatory skin disorders [28] and spontaneous fetal loss [29]. Nevertheless, the expression of CD200/CD200R1 has not been determined in patients with IBD. Therefore, we aimed to investigate the frequencies of DCs expressing CD200 or CD200R1 using flow cytometry and correlate the results with Treg $\left(\mathrm{CD} 4^{+} \mathrm{CD} 25^{+}\right)$, Th17 $\left(\mathrm{CD} 4^{+} \mathrm{IL}-17^{+}\right)$and routine biochemical and serological markers in children with IBD.

\section{Results}

\subsection{Patient Characteristics}

Thirty-seven pediatric patients with IBD were included; 23 of them have CD (nine female and 14 male) and 14 UC (four female/10 male). The age range of patients was 9-15 years (mean age $13.25 \pm 2.9$ years) (Table 1$)$. IBD patients had a significant weight reduction $(p<0.001)$ compared to control subjects. The mean duration of the disease was more than six months in $50 \%$ of UC and in $61 \%$ of children with CDs. For the patients with $\mathrm{CD}$, the disease location was confined to the terminal ileum in eight $(34.8 \%)$, colon in four $(17.4 \%)$ or ileocolon in $11(47.8 \%)$ patients, and the 
disease behavior was non-stricturing, non-penetrating in $16(69.6 \%)$, stricturing in four $(17.4 \%)$ or perforating in three $(13.04 \%)$ patients accordingly. For the patients with UC, disease was classified according to the Paris classification to ulcerative proctitis and left-sided UC in four (28.6\%), extensive to hepatic flexure in two (14.3\%) and extensive separately (pancolitis) in eight (57.1\%). Disease activity assessed according to the Mayo Clinical Colitis Activity Index was found moderate in five (35.7\%) and severe in nine $(64.3 \%)$ patients. The majority of $\mathrm{CD}$ and UC patients had been treated with the combination of aminosalicylate (5-ASA) mesalamine with one of the immunosuppressive drugs prednisolone, azathioprine or infliximab.

Table 1. Characteristics of IBD patients and healthy controls included in the study.

\begin{tabular}{|c|c|c|c|}
\hline Parameter & Ulcerative Colitis $(n=14)$ & Crohn's Disease $(n=23)$ & Healthy Control $(n=14)$ \\
\hline Age (years) & $13.25 \pm 2.94$ & $13.73 \pm 3.10$ & $15.21 \pm 2.41$ \\
\hline $\operatorname{Sex}(\mathrm{M} / \mathrm{F})$ & $4 / 10$ & $9 / 14$ & $5 / 9$ \\
\hline Weight (kg) & $21.43 \pm 1.51$ & $33.79 \pm 3.89$ & $47.9 \pm 4.73$ \\
\hline Height $(\mathrm{cm})$ & $114 \pm 3.09$ & $136.95 \pm 5.07$ & $152.8 \pm 7.67$ \\
\hline $\begin{array}{l}\text { Disease duration } \\
\quad \text { (months.) }\end{array}$ & $7 \pm 3.16$ & $9 \pm 4.01$ & \\
\hline \multicolumn{4}{|c|}{ Paris classification } \\
\hline & Left-sided 4 (28.6\%) & Terminal ileum 8 (34.8\%) & \\
\hline Location & Extensive $2(14.3 \%)$ & Colon $4(17.4 \%)$ & \\
\hline & Pancolitis $8(57.1 \%)$ & Ileocolon in $11(47.8 \%)$ & \\
\hline Behavior & $\mathrm{N} / \mathrm{A}$ & $\begin{array}{c}\text { Non-stricturing, } \\
\text { non-penetrating } 16(69.6 \%) \\
\text { Stricturing } 4(17.4 \%) \\
\text { Perforating } 3(13.04 \%)\end{array}$ & \\
\hline Mayo score & $\begin{array}{c}\text { Mild } 0 \\
\text { Moderate } 5(35.7 \%) \\
\text { Severe } 9(64.3 \%)\end{array}$ & $\mathrm{N} / \mathrm{A}$ & \\
\hline Rectal bleeding & $14(100 \%)$ & $13(56.5 \%)$ & \\
\hline Diarrhea & $14(100 \%)$ & $19(82.6 \%)$ & \\
\hline \multicolumn{4}{|c|}{ Therapy } \\
\hline Prednisone & $12(85.7 \%)$ & $23(100 \%)$ & \\
\hline Mesalamine & $14(100 \%)$ & $18(78.3 \%)$ & \\
\hline Azathioprine & $12(85.7 \%)$ & $23(100 \%)$ & \\
\hline Sulfasalazine & 0 & $10(43.5 \%)$ & \\
\hline
\end{tabular}

N/A: not applicable.

\subsection{Biochemical and Serological Markers}

Erythrocyte sedimentation rate (ESR), C-reactive protein (CRP) and alkaline phosphatase (ALP) are known to be good predictors of disease activity in IBD. CD patients showed significantly higher CRP than UC and control subjects $(p<0.05,0.01$ respectively). Patients with CD and UC had significantly higher levels of ESR and ALP compared to healthy controls, while no significant differences were detected between the two patient groups. Sera from patients and healthy controls were also tested for anti-Saccharomyces cerevisiae antibodies (ASCA) and perinuclear antineutrophilic cytoplasmic antibody (pANCA), and it was found that none of the control group had these autoantibodies. UC patients had significantly higher pANCA than CD patients did (35.7\% vs. $17.4 \% ; p<0.01$ ). Both ASCA-IgG and ASCA-IgA were significantly higher in CD than UC patients (Table 2).

Figure 1 shows that the serum levels of IL-17, IL-10, IL-12 and TNF- $\alpha$ were found to be increased in IBD patients compared to healthy control children. However, significant differences were only 
found in serum IL-17 of both patient groups (both at $p<0.01$ ) and in the TNF- $\alpha$ levels of UC patients $(p<0.05)$ compared to healthy children.

Table 2. Biochemical and serological parameters.

\begin{tabular}{cccc}
\hline Marker & Ulcerative Colitis $(\boldsymbol{n = 1 4 )}$ & Crohn's Disease $(\boldsymbol{n = 2 3 )}$ & Healthy Control $(\boldsymbol{n}=\mathbf{1 4})$ \\
\hline ALP $(\mathrm{IU} / \mathrm{L})$ & $175.29 \pm 32.24^{\mathrm{aa}, \mathrm{b}}$ & $195.15 \pm 27.05^{\text {aa }}$ & $67.2 \pm 12.74$ \\
CRP $(\mathrm{mg} / \mathrm{dL})$ & $13.57 \pm 4.46^{\mathrm{aa}, \mathrm{b}}$ & $34.05 \pm 8.56^{\text {aa }}$ & $3.42 \pm 1.07$ \\
ESR (mm/H) & $30 \pm 4.08^{\mathrm{a}}$ & $35.5 \pm 6.23^{\mathrm{a}}$ & $11.2 \pm 2.1$ \\
pANCA & $5(35.7)^{\mathrm{bb}}$ & $4(17.4 \%)$ & 0 \\
ASCA-IgA & $2(14.2 \%)^{\mathrm{bb}}$ & $6(26.1) \%$ & 0 \\
ASCA-IgG & $3(21.4 \%)^{\mathrm{b}}$ & $7(30.4 \%)$ & 0 \\
\hline
\end{tabular}

${ }^{a}$ Denotes statistically-significant difference compared to the control: ${ }^{a}: p<0.05$, ${ }^{\text {aa }}: p<0.01$; ${ }^{b}$ Denotes statistical significance compared to Crohn's disease (CD): ${ }^{\mathrm{b}}: p<0.05,{ }^{\mathrm{bb}}: p<0.01$. Values represent the mean \pm standard deviations.
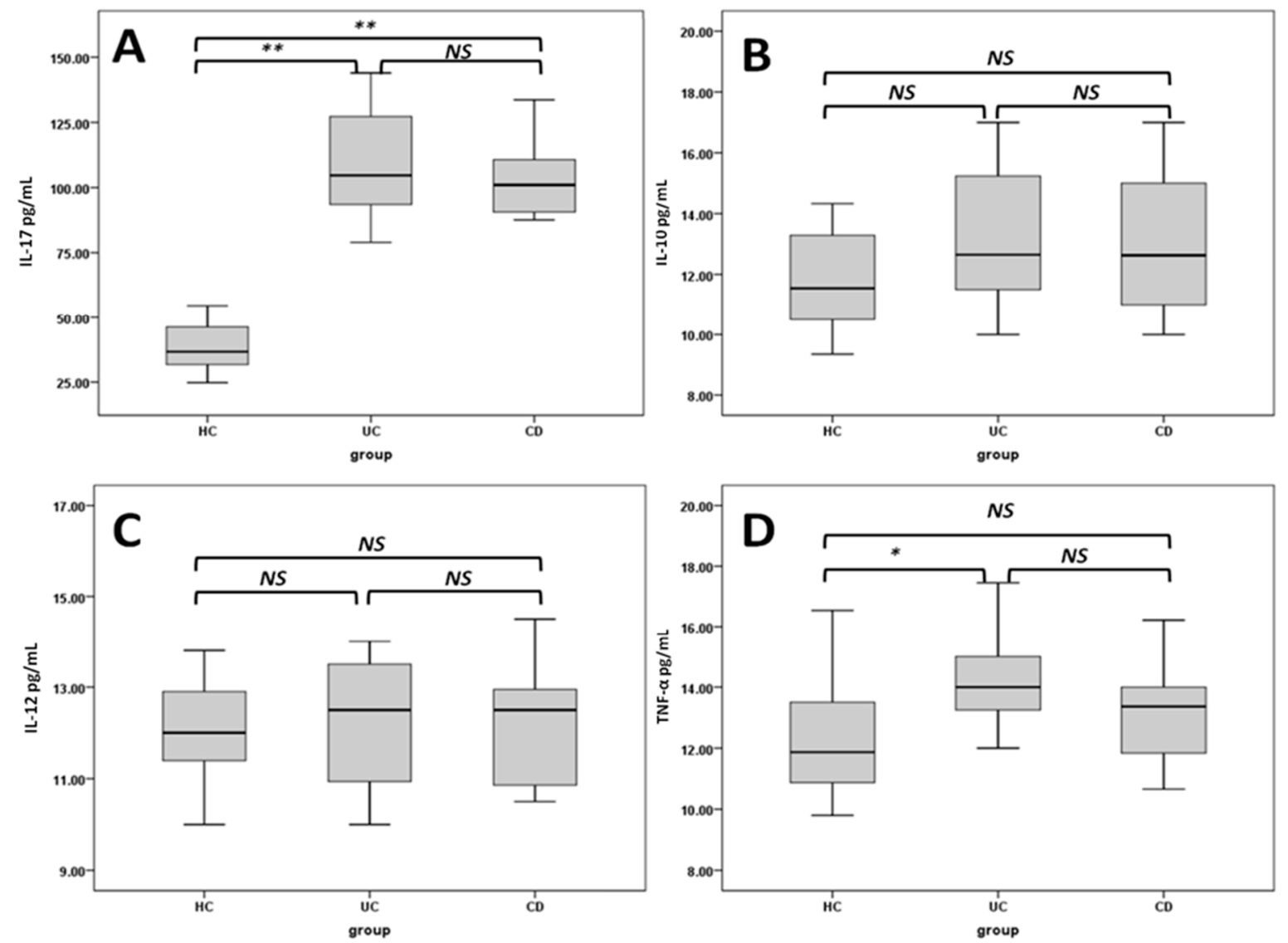

Figure 1. Box plots show the concentrations of IL-17 (A), IL-10 (B), IL-12 (C) and TNF- $\alpha$ cytokines (D) in the studied groups. HC: healthy controls; UC: ulcerative colitis patients; CD: Crohn's disease patients; NS: not significant; ${ }^{*} p<0.05 ;{ }^{* *} p<0.005$.

\subsection{Reduced DCs Expressing CD200R1 and Increased CD200+DCs}

Figure 2 demonstrates a flow cytometric analysis of dendritic cell subsets (myeloid dendritic cells (mDCs) and plasmacytoid DCs (pDCs)) and the frequencies of both DCs expressing CD200 and CD200R1 cell surface proteins. The percentage of $\mathrm{mDC}$ and pDCs expressing CD200R1 and CD200 molecules is presented in Figure 3. pDCs expressing CD200R1 in patients with CD and UC were significantly lower than those of healthy controls (HCs) $(26.61 \pm 5.17,21.12 \pm 5.0$ vs. $40.24 \pm 7.05$, both at $p<0.005)$. The expression of CD200R1 on mDCs also was significantly lower in patients with 
CD and UC compared to HCs $(3.1 \pm 1.7,2.49 \pm 1.4$ vs. $10.37 \pm 3.3$, both at $p<0.005)$. In the meantime, we found that $\mathrm{pDC}$ expressing CD200 were significantly increased in CD and UC patients compared to HCs $(17.49 .1 \pm 4.0,21.1 \pm 4.45$ vs. $8.7 \pm 3.7$, both at $p<0.005)$. mDCs expressing CD200 were also found to be significantly increased in CD and UC compared to HCs $(7.99 \pm 2.4,10.31 \pm 1.6$ vs. $3.99 \pm 1.5, p<0.05$ and 0.005 , respectively).
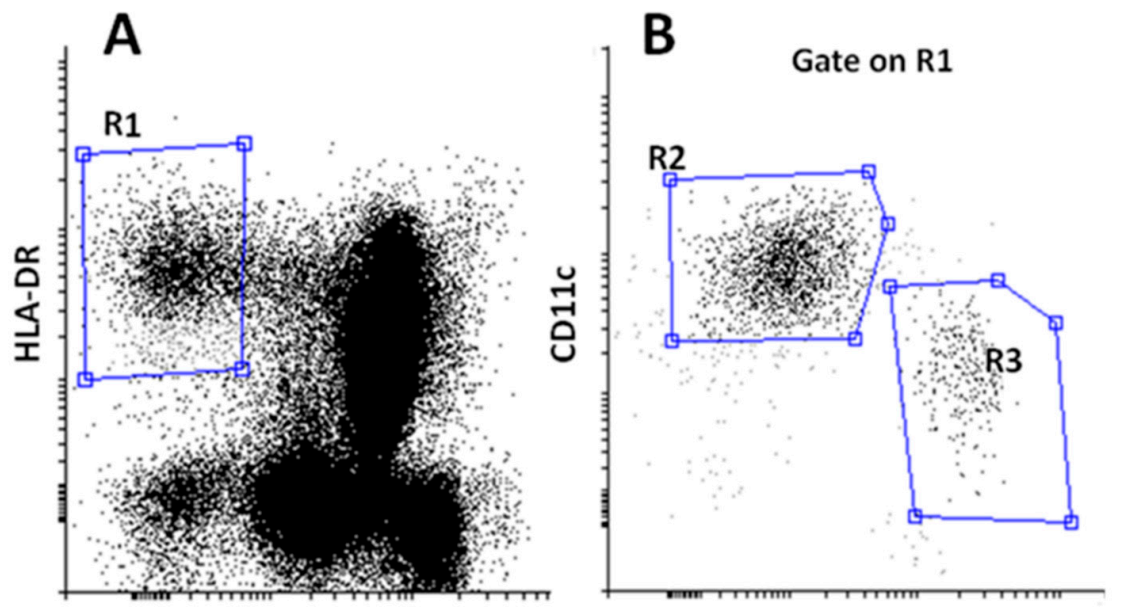

Lin

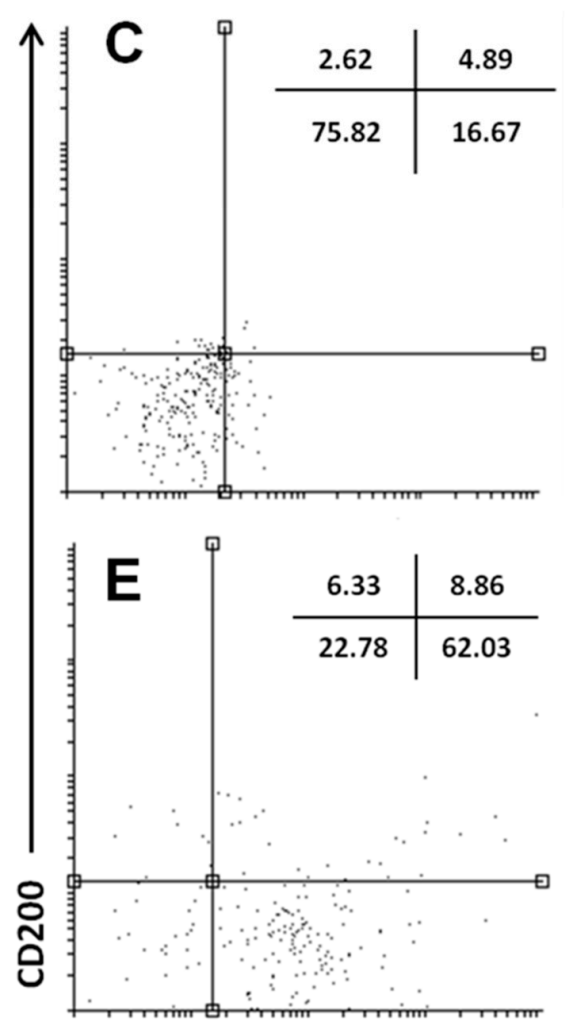

CD123

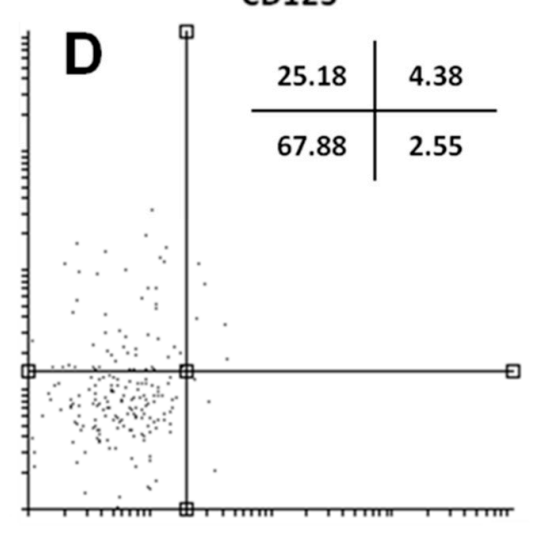

\section{CD200R1}

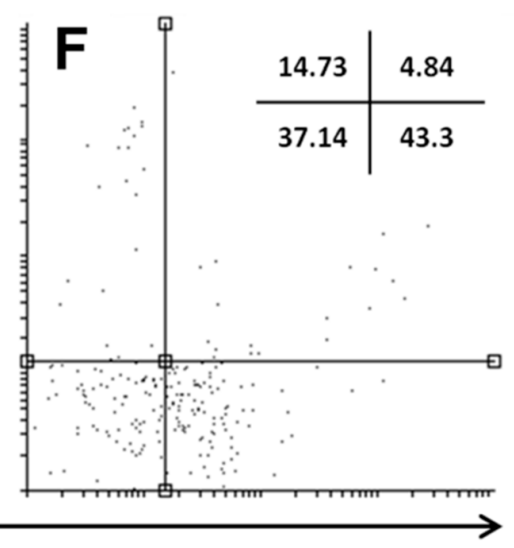

Figure 2. Representative flow cytometry data to illustrate the gating strategy for FACS analysis of DC subsets. (A) Dendritic cell HLA-DR ${ }^{+} \mathrm{Lin}^{-}$cells were gated (R1), and myeloid CD11c ${ }^{+} \mathrm{mDCs}(\mathbf{R} 2)$, plasmacytoid $\mathrm{CD}_{123^{+}} \mathrm{pDCs}(\mathbf{R} 3)$ were determined as a percentage of the total PBMC (B). Dot plots to illustrate the expression of CD200 and CD200R1 on the myeloid dendritic cell (mDC) subset of healthy controls and IBD patients (C,D) and on and plasmacytoid DCs (pDCs) of healthy controls and IBD patients (E,F). 

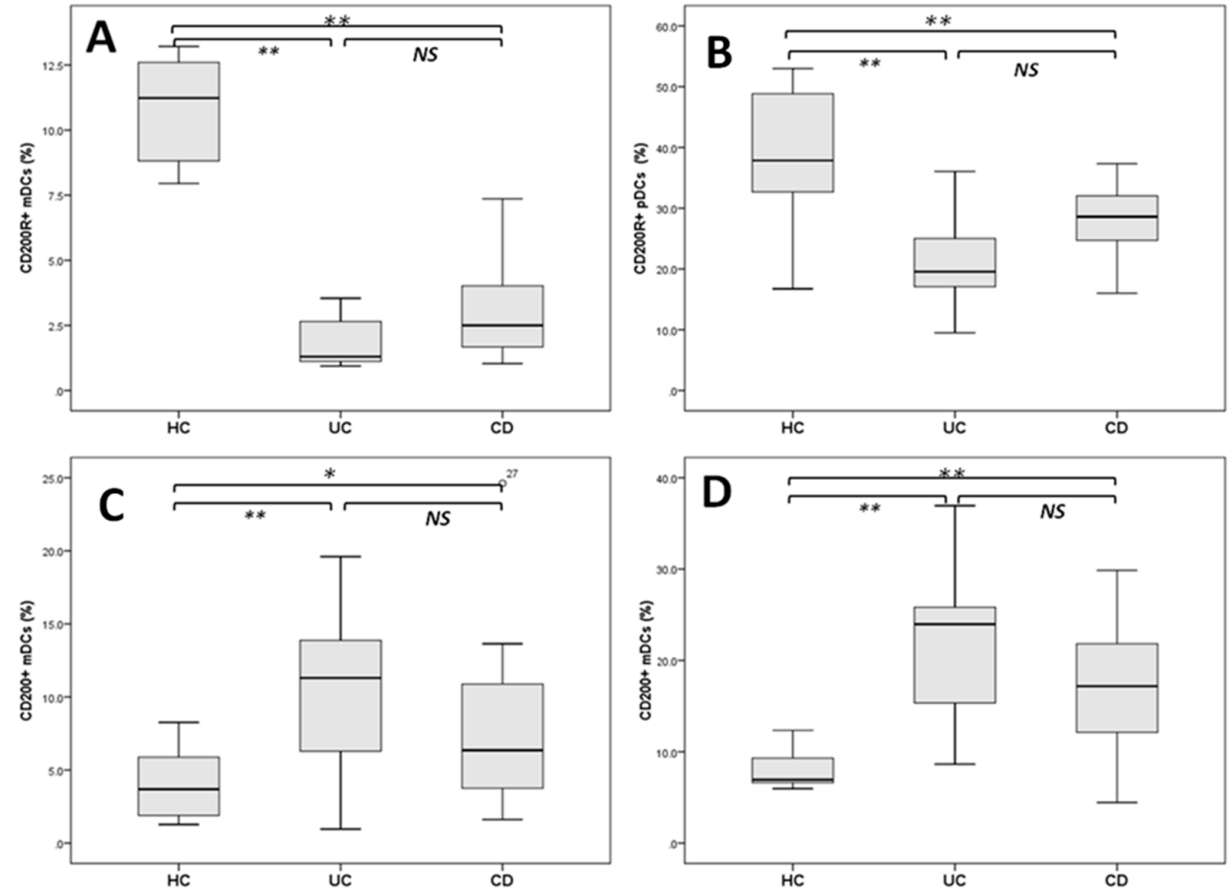

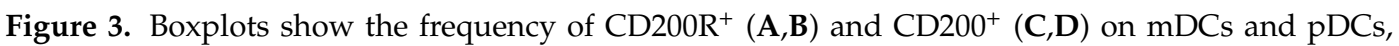
respectively. HC: healthy controls; UC: ulcerative colitis patients; CD: Crohn's disease patients; NS: not significant; ${ }^{*} p<0.05 ;{ }^{* *} p<0.005$.

\subsection{Regulatory T Cells and TH17 Cells}

Regulatory T cells, as identified by flow cytometry based on the expression of CD4, CD25 and Foxp3, were found significantly decreased in UC and CD patients compared to healthy controls (both at $p<0.01$ ) (Figure $4 \mathrm{~A}$ ). Th17 cells were determined with intracellular staining of IL-17 in CD4 ${ }^{+} \mathrm{T}$ cells by flow cytometry, after in vitro stimulation by phorbol myristate acetate (PMA)/ionomycin in short-term culture. The percentage of Th17 was found significantly increased in CD compared to UC patients and healthy subjects $(2.01 \% \pm 0.28 \%$ vs. $1.06 \% \pm 0.16 \%$ and $0.95 \% \pm 0.14 \%, p<0.01,0.001$, respectively) $(p<0.001)$. Patients with UC displayed an increased percentage of Th17 cells when compared to that of healthy controls $(p<0.001)$ (Figure 4B).
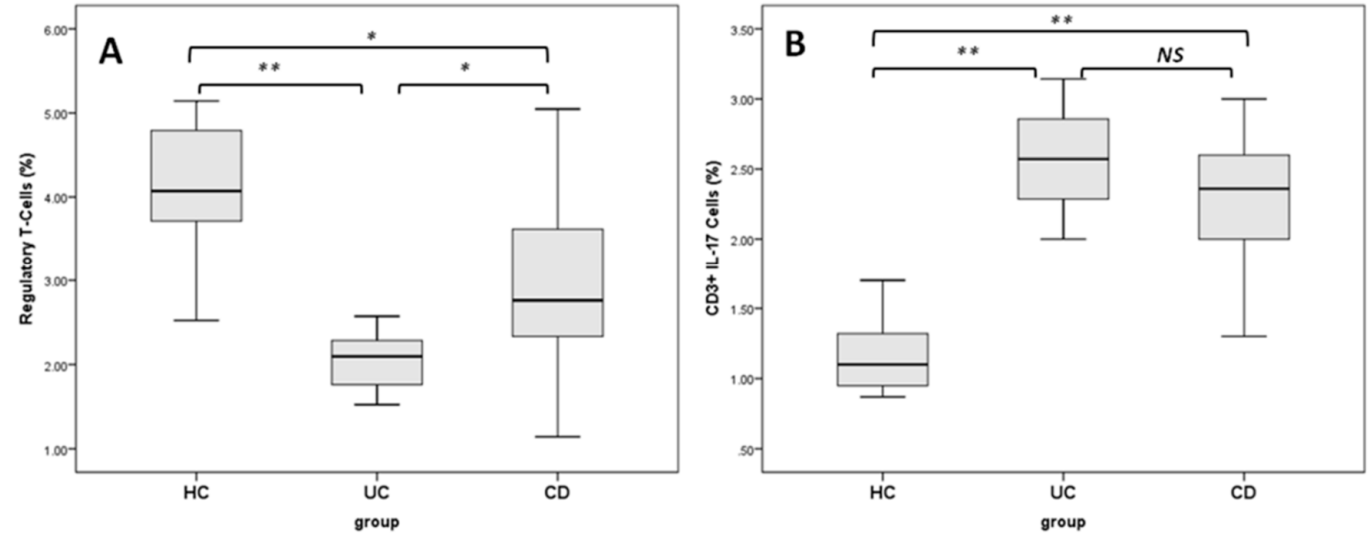

Figure 4. Boxplots show the frequency of Treg (A) and Th17 (B) among different groups. HC: healthy controls; UC: ulcerative colitis patients; CD: Crohn's disease patients; NS: not significant; ${ }^{*} p<0.05$; ** $p<0.005$. 


\subsection{Correlation Analyses}

Correlation analysis showed that none of the biochemical parameters correlated significantly with CD200 or CD200R1, except for ESR and the serum concentration of IL-17, which showed significant negative correlations with $\mathrm{DCs}^{+} \mathrm{CD} 200 \mathrm{R} 1^{+}(p<0.01, p<0.001$, respectively).

Table 3 shows that the percentage of Treg was found significantly correlated with CD200R $\mathrm{R}^{+}$ mDCs $(r=0.383, p=0.023)$ and CD200R ${ }^{+}$pDCs $(r=0.406, p<0.01)$. On the contrary, mDCs and pDCs expressing CD200 showed significant negative correlations with Treg $(r=-0.420, p<0.01 ; r=$ $-0.576, p<0.001$, respectively). mDCs expressing CD200R1 were found negatively correlated with Th17 $(r=-0.633, p<0.0001)$, whereas CD200 ${ }^{+}$mDCs did not correlate significantly with Th17. pDCs expressing the CD200R1 population were correlated negatively with Th17 CD4 ${ }^{+}$cells $(r=-0.319, p<$ $0.05)$; whereas, the CD200 ${ }^{+}$pDC population was found significantly correlated with Th17 $(r=0.416$, $p<0.01$ ) (Table 3).

Table 3. Correlations of Treg and Th17 with DC subsets expressing CD200R1 or CD200.

\begin{tabular}{ccc}
\hline Parameter & Treg & Th17 \\
\hline mDCs & $-0.103(0.568)$ & $0.441(0.008)^{* *}$ \\
pDCs & $-0.245(0.169)$ & $0.104(0.552)$ \\
CD200R1 ${ }^{+}$mDCs & $0.383(0.023)^{*}$ & $-0.412(0.011)^{*}$ \\
CD200 ${ }^{*}$ DCs & $-0.420(0.01)^{* *}$ & $0.193(0.251)$ \\
CD200R1 ${ }^{+}$pDCs & $0.406(0.012)^{*}$ & $-0.319(0.001)^{* *}$ \\
CD200 ${ }^{*}$ pDCs & $-0.576(0.001)^{* *}$ & $0.416(0.009)^{* *}$ \\
\hline
\end{tabular}

** Correlation is significant at the 0.01 level (2-tailed); ${ }^{*}$ correlation is significant at the 0.05 level (2-tailed); values represent the correlation coefficient $r$ ( $p$-value).

\section{Discussion}

Besides their widely-recognized role as professional antigen-presenting cells in activating $\mathrm{T}$ cells, DCs are essential in the regulation of both central and peripheral tolerance. DCs induce tolerance by triggering apoptosis of autoreactive $\mathrm{T}$ cells in the thymus (central tolerance) and by their interactions with $\mathrm{T}$ cells in the periphery, causing the induction of $\mathrm{T}$ cell anergy, $\mathrm{T}$ cell apoptosis or the induction of regulatory T cells (Treg) (peripheral tolerance) [30]. DCs possess several costimulatory molecules and immune receptors that enable them to mediate these opposing tasks [31]. CD200R is an inhibitory receptor mainly expressed on myeloid cells that is able to regulate the activation threshold of inflammatory immune responses, both in vivo and in vitro [32]. CD200, the ligand of CD200R, is a widely-expressed glycoprotein on a wide variety of cells throughout the body. Strong evidence indicates that the interaction between CD200 and CD200R1 is implicated in the development of tolerogenic DCs that preferentially induce populations of $\mathrm{CD} 4{ }^{+} \mathrm{CD} 25^{+}$regulatory $\mathrm{T}$ cells (Treg) [16] and initiate the immunosuppressive pathway of tryptophan catabolism [12], capable of dampening or preventing immune responses.

In humans, there are two major subsets of circulating DCs that have been identified, termed myeloid (mDCs) and plasmacytoid DCs (pDCs) [33]. pDCs play also a vital role in the induction of oral tolerance, since they prevent oral $\mathrm{T}$ cell priming and are responsible for systemic tolerance to dietary antigens, including proteins and haptens [34]. pDCs were further shown to complement the role of Treg cells in inducing oral tolerance initiated in the gut [35]. In contrast, mDCs are highly effective at antigen presentation and $\mathrm{T}$ cell stimulation and have the capacity to produce Th1 and induce Th17 responses [36]. In agreement with these data, we found that mDCs correlate significantly with Th-17.

In our study, the percentage of pDCs expressing the tolerance molecule CD200R in healthy controls was higher $(40 \%$ and $50 \%$ of whole pDCs) than that of mDCs (around $10 \%$ of whole blood $\mathrm{mDCs})$, suggesting that $\mathrm{pDCs}$ are more tolerogenic than mDCs. These observations are in line with previous preclinical and clinical trials suggesting that $\mathrm{pDCs}$ exert a stronger immune suppression 
compared to mDCs and preferentially induce the differentiation of allogeneic Treg $[37,38]$ and, thus, are generally defined as tolerogenic dendritic cells.

In patient groups, our data demonstrate a significant decrease in tolerogenic pDCs expressing CD200R. This finding may provide an explanation for the observed exaggerated inflammatory response of circulating mDCs to lipopolysaccharide (LPS) in patients with inflammatory bowel disease that was reported earlier by Baumgart et al. [39]. Furthermore, the percentage of CD200R ${ }^{+}$ DCs was found to be significantly correlated positively with $\mathrm{CD} 4{ }^{+} \mathrm{CD} 25^{+}$Treg and to have a significant negative correlation with TH17 cells. These data are in agreement with Ochando et al. [40], who reported that pDCs can induce the generation of $\mathrm{CD} 4^{+} \mathrm{CD} 25^{+} \mathrm{Foxp} 3^{+}$Treg cells and that depletion of pDCs or prevention of pDC lymph node homing inhibited peripheral Treg cell development and tolerance induction.

Recently, it has been demonstrated that Th17 and Treg cells have a functional antagonism, in which Tregs act as immunosuppressive cells, and Th17 cells are involved in initiating autoimmune and inflammatory diseases [41]. The balance between Treg and Th17 cells is tightly regulated. Dysregulation of this balance can lead to inflammation and autoimmunity. Interestingly, we found that the reduction in CD200R+ DCs is associated with increased TH17, and decreased Treg cells may give a clue to elucidate the cause of TH17/Treg imbalance, which is possibly the leading cause of IBD, as suggested by Eastaff-Leung et al. [42].

On the contrary, we found that IBD patients have a significant increase in DCs expressing CD200, both in UC and CD patients. In addition, we found a significant positive correlation between CD200 ${ }^{+}$pDCs and Th17. CD200 has one major difference from CD200R in that it does not contain signaling motifs or docking domains in its short cytoplasmic tail; therefore, no direct effect was observed on cells expressing it upon its binding to CD200R [43]. Actually, several studies have indicated that CD200 imparts a unidirectional negative signal on binding to CD200R-bearing cells [32,44]. Mukhopadhyay et al. [45] demonstrated that induction of CD200 limits cell activation and protects the host from excessive inflammation. In addition, upregulation of CD200 expression was found to be associated with diminished proinflammatory cytokine production to self-antigens [46]. Based on these data and our results, it can be suggested that the increase in DCs expressing C200 may be considered as a compensatory mechanism to downregulate their exaggerated inflammatory immune response, as previously suggested by Jurgens et al. [47].

\section{Experimental Section}

\subsection{Study Population}

The study included 37 consecutive unselected cases with IBD that were referred to the outpatient Pediatrics Clinic of King Abdulaziz University Hospital (KAUH, Jeddah, Saudi Arabia) during the period from May 2013 to May 2014. Demographic and clinical data were collected from all patients, including gender, ethnicity, age, age at diagnosis, disease activity, their history of surgery related to IBD, chronic steroid use (including steroid-dependent or steroid-refractory disease) and the presence of side effects of medical treatment. The disease activity was assessed according to the Paris modification of the Montreal classification for IBD [48]. The clinical activity of UC patients was evaluated according to the Mayo score [49]. Patients were excluded if they had incomplete ileocolonoscopy, microscopic colitis, infectious ileocolitis, colorectal cancer, colorectal polyps, unclear diagnosis, urinary incontinence, no fecal samples, viral infection (HIV, hepatitis B or C), chronic steroid use (including steroid-dependent or steroid-refractory disease) and the presence of side effects of medical treatment. Fourteen age-matched pediatric volunteers ( 5 males and 9 females), who were clinically and laboratory free of any autoimmune diseases, served as a healthy control group. For understandable reasons, subjects in the healthy control group had no endoscopic workup. The study protocol was approved by the Ethics Committee of the KAUH, and the study has been conducted according to the principles expressed in the Declaration of Helsinki. Patients or one of 
their parents were informed of the nature of the investigation and were instructed to complete the questionnaire. The clinical characteristics of the patients are shown in Table 1.

\subsection{Sample Preparations}

Ten milliliters of blood were drawn from each participant. Each blood sample was divided into two equal parts; $5 \mathrm{~mL}$ of blood were collected in serum separator tubes, centrifuged and assayed immediately for routine biochemistry tests. The other part of the blood sample was collected into tubes with anticoagulant ethylenediaminetetraacetic acid (EDTA) for isolation of PBMCs from whole blood using Ficoll-Paque (GE Health Care, Boston, PA, USA) density gradient centrifugation. Cells were washed once with RPMI-1640 (BioWhittaker, Walkersville, MD, USA) and prepared for flow cytometry assays.

\subsection{Biochemical and Serological Investigations}

The serum concentrations of C-reactive protein (CRP), erythrocyte sedimentation rate (ESR), ALB (albumin), ALT (alanine aminotransferase), AST (aspartate aminotransferase), ALP (alkaline phosphatase) and GGT (glutamyl transferase) were analyzed using commercially available kits (Dade-Behring, Marburg, Germany) according to the manufacturer's instructions. The levels of IgG and IgA antibodies to ASCA were detected in serum using ELISA kits (Inova Diagnostics Inc., San Digo, CA, USA) that were performed in duplicate according to the manufacturer's instructions. pANCA was analyzed by ELISA and indirect immunofluorescence, as previously described [50]. The concentrations of TNF- $\alpha$, IL-17, IL-12p40 and IL-10 were determined in the sera of all of the participants by the enzyme linked immunosorbent assay (ELISA) using the Quantikine kits (R\&D Systems, Minneapolis, MN, USA). The minimum detectable levels using the ELISA kits were $5.5 \mathrm{pg} / \mathrm{mL}$ for TNF- $\alpha, 15 \mathrm{pg} / \mathrm{mL}$ for IL-17, $5 \mathrm{pg} / \mathrm{mL}$ for IL-12, $3.9 \mathrm{pg} / \mathrm{mL}$ for IL-10. The tests were conducted according to the manufacturer's instructions.

\subsection{Flow Cytometry Assays}

\subsubsection{Dendritic Cells Subsets Analysis}

Plasmacytoid and myeloid subsets of DCs from PBMCs were identified by multiparametric flow cytometry as described elsewhere [51]. Briefly, $100 \mu \mathrm{L}$ of PBMCs were stained with FITC-lineage cocktail 1 (consists of anti-CD3, -CD14, -CD16, -CD19, -CD20 and -CD56) (Becton Dickinson, San Jose, CA, USA), PE-CD200R1 (Clone 380525, R\&D Systems), PerCP-CD123 (Clone 32703, R\&D systems), APC-CD200 (Clone 380525, R\&D Systems), AF700-CD11c (Clone ICRF 3.9, R\&D systems) and PE-Cy7-HLA-DR (Clone L243, BD-biosciences, San Jose, CA, USA). Isotype-matched control $\mathrm{mAbs}$ were used to determine the nonspecific binding. Flow cytometry analysis was performed on a Navios flow cytometer (Beckman-Coulter Inc., Brea, CA, USA). Fifty thousand events were acquired, and data were analyzed with the Summit v4.3 Build 2445 software (Dako-cytomation Inc., Carpinteria, CA, USA). Cells were gated by their forward- and side-scatter properties and identified further by specific surface markers. The lineage-negative cells were analyzed for the expression of CD11c, CD123 and human leukocyte antigen (HLA)-DR. Plasmacytoid DCs (pDCs) were identified as cells double-positive for CD123 and HLA-DR, while myeloid DCs (mDCs) were identified as cells double positive for CD11C and HLA-DR (Figure 1A). Percentages of CD200 and CD200R1 were determined after gating on mDCs and pDCs (Figure 1C,D).

\subsubsection{Regulatory T Cells Analysis}

For regulatory $\mathrm{T}$ cell staining, $1 \times 10^{6}$ cells were resuspended in $100 \mu \mathrm{L}$ flow cytometry staining buffer (R\&D Systems, Minneapolis, MN, USA). Cells were incubated with FITC-labelled anti-CD4 (clone FAB3791F, R\&D Systems) and APC-labelled anti-CD25 (clone BC96, R\&D Systems) antibodies for $30 \mathrm{~min}$ at $4{ }^{\circ} \mathrm{C}$ in the dark. For intracellular staining, after permeabilization with 
fixation/permeabilization buffer (R\&D Systems), phycoerythrin (PE)-labelled anti-Foxp3 antibody (clone IC8214P, R\&D Systems) was added and incubated for $30 \mathrm{~min}$ at $4{ }^{\circ} \mathrm{C}$ in the dark. FITC- and APC-conjugated mouse IgG2a and PE-conjugated rabbit IgG antibodies were used as the isotype control antibodies.

\subsubsection{Th17 Cells' Analysis}

PBMCs were cultured in RPMI-1640 complete medium supplemented with 10\% $(v / v)$ FBS, $2.0 \mathrm{mM}$ L-glutamine, $50 \mathrm{mM}$ 2-mercaptoethanol, $100 \mathrm{U} / \mathrm{mL}$ penicillin and $100 \mathrm{mg} / \mathrm{mL}$ streptomycin. Cells were activated with $50 \mathrm{ng} / \mathrm{mL}$ phorbol myristate acetate (PMA) plus $1.0 \mu \mathrm{g} / \mathrm{mL}$ of ionomycin for $6 \mathrm{~h}$ in the presence of $0.5 \mu \mathrm{g} / \mathrm{mL}$ brefeldin-A (all from Sigma-Aldrich, St. Louis, MO, USA); then, cells were fixed for $10 \mathrm{~min}$ at room temperature with PBS containing $4 \%$ paraformaldehyde (Sigma-Aldrich). The control PBMCs were cultured in medium alone. The stimulated PBMCs were harvested and stained with FITC-labeled anti-CD4. After $30 \mathrm{~min}$ of incubation, cells were fixed with the Perm/Fix solution, and permeabilized, followed by staining with PerCP-labeled anti-IL-17 (Clone 41802, R\&D Systems). Ten thousand events were acquired by flow cytometry, and the percentages of cells producing IL-17 cytokine were determined after gating on CD4 $4^{+}$lymphocytes. Appropriate conjugated IgG antibodies were used as isotype controls. All flow cytometry data were acquired on a Beckman-Coulter Navios cytometer (Beckman-Coulter Inc., Brea, CA, USA) and analyzed with Summit software (Dako-cytomation Inc., Carpinteria, CA, USA).

\subsection{Statistical Analysis}

All data were statistically analyzed using the Statistical Package for Social Sciences (SPSS) V20.0. The data were expressed as the means \pm standard deviation (SD). Correlations were done using the Pearson tests, and analyses of variance were done using the ANOVA test followed by Bonferroni correction. A $p$-value less than or equal to 0.05 is considered as being statistically significant.

\section{Conclusions}

In summary, our study demonstrates that IBD is characterized by a decreased prevalence of mDCs and pDCs expressing the inhibitory molecule CD200R. Furthermore, our data show that CD200R1 expression on DCs correlates positively with circulating Treg and negatively with ESR and Th17. Finally, our findings suggest that DCs are implicated in the pathogenesis of IBD and that they exert their effects, at least in part, through modulation of Th17/Treg balance. Further functional studies, as well as expanding investigation on other cells and mediators of immune responses and inflammation are currently in progress by our research group to better elucidate the molecular mechanism of IBD and to provide a basis for identifying novel therapeutic targets in those autoimmune disorders.

Acknowledgments: The authors would like to express their sincere appreciation to the Deanship of Scientific Research at the King Abdulaziz University, Jeddah, Saudi Arabia, for funding this Research Group Project No. $\mathrm{RG} / 32 / 02$.

Author Contributions: Conceived of and designed the experiments: Mohamed F. Elshal, Alia M. Aldahlawi, Omar I. Saadah, J. Philip McCoy. Performed the experiments: Mohamed F. Elshal, Alia M. Aldahlawi. Analyzed the data: Mohamed F. Elshal, Alia M. Aldahlawi, J. Philip McCoy. Contributed samples/materials/analysis tools: Mohamed F. Elshal, Alia M. Aldahlawi, Omar I. Saadah, J. Philip McCoy. Wrote the paper: Mohamed F. Elshal, J. Philip McCoy.

Conflicts of Interest: The authors declare no conflict of interest. 


\section{References}

1. Lennard-Jones, J.E. Classification of inflammatory bowel disease. Scand. J. Gastroenterol. 1989, 170, $2-69$. [CrossRef]

2. Benchimol, E.I.; Manuel, D.G.; Guttmann, A.; Nguyen, G.C.; Mojaverian, N.; Quach, P.; Mack, D.R. Changing age demographics of inflammatory bowel disease in Ontario, Canada: A population-based cohort study of epidemiology trends. Inflamm. Bowel Dis. 2014, 20, 1761-1769. [CrossRef] [PubMed]

3. Malaty, H.M.; Fan, X.; Opekun, A.R.; Thibodeaux, C.; Ferry, G.D. Rising incidence of inflammatory bowel disease among children: A 12-year study. J. Pediatr. Gastroenterol. Nutr. 2010, 50, 27-31. [CrossRef] [PubMed]

4. Martin-de-Carpi, J.; Rodriguez, A.; Ramos, E.; Jimenez, S.; Martinez-Gomez, M.J.; Medina, E. SPIRIT-IBD Working Group of Sociedad Española de Gastroenterología, Hepatología y Nutricion Pediátrica. Increasing incidence of pediatric inflammatory bowel disease in Spain (1996-2009): The SPIRIT Registry. Inflamm. Bowel Dis. 2013, 19, 73-80. [CrossRef] [PubMed]

5. Hviid, A.; Svanstrom, H.; Frisch, M. Antibiotic use and inflammatory bowel diseases in childhood. Gut 2011, 60, 49-54. [CrossRef] [PubMed]

6. Xavier, R.J.; Podolsky, D.K. Unravelling the pathogenesis of inflammatory bowel disease. Nature 2007, 448, 427-434. [CrossRef] [PubMed]

7. Sartor, R.B. Mechanisms of disease: Pathogenesis of Crohn's disease and ulcerative colitis. Nat. Clin. Pract. Gastroenterol. Hepatol. 2006, 3, 390-407. [CrossRef] [PubMed]

8. Frank, D.N.; St Amand, A.L.; Feldman, R.A.; Boedeker, E.C.; Harpaz, N.; Pace, N.R. Molecular-phylogenetic characterization of microbial community imbalances in human inflammatory bowel diseases. Proc. Natl. Acad. Sci. USA 2007, 104, 13780-13785. [CrossRef] [PubMed]

9. Rakoff-Nahoum, S.; Paglino, J.; Eslami-Varzaneh, F.; Edberg, S.; Medzhitov, R. Recognition of commensal microflora by toll-like receptors is required for intestinal homeostasis. Cell 2004, 118, 229-241. [CrossRef] [PubMed]

10. Elson, C.O.; Cong, Y.; McCracken, V.J.; Dimmitt, R.A.; Lorenz, R.G.; Weaver, C.T. Experimental models of inflammatory bowel disease reveal innate, adaptive, and regulatory mechanisms of host dialogue with the microbiota. Immunol. Rev. 2005, 206, 260-276. [CrossRef] [PubMed]

11. Hawiger, D.; Inaba, K.; Dorsett, Y.; Guo, M.; Mahnke, K.; Rivera, M.; Ravetch, J.V.; Steinman, R.M.; Nussenzweig, M.C. Dendritic cells induce peripheral T cell unresponsiveness under steady state conditions in vivo. J. Exp. Med. 2001, 194, 769-779. [CrossRef] [PubMed]

12. Fallarino, F.; Asselin-Paturel, C.; Vacca, C.; Bianchi, R.; Gizzi, S.; Fioretti, M.C.; Trinchieri, G.; Grohmann, U.; Puccetti, P. Murine plasmacytoid dendritic cells initiate the immunosuppressive pathway of tryptophan catabolism in response to CD200 receptor engagement. J. Immunol. 2004, 173, 3748-3754. [CrossRef] [PubMed]

13. Lee, G.K.; Park, H.J.; Macleod, M.; Chandler, P.; Munn, D.H.; Mellor, A.L. Tryptophan deprivation sensitizes activated T cells to apoptosis prior to cell division. Immunology 2002, 107, 452-460. [CrossRef] [PubMed]

14. Hwu, P.; Du, M.X.; Lapointe, R.; Do, M.; Taylor, M.W.; Young, H.A. Indoleamine 2,3-dioxygenase production by human dendritic cells results in the inhibition of T cell proliferation. J. Immunol. 2000, 164, 3596-3599. [CrossRef] [PubMed]

15. Holmannova, D.; Kolackova, M.; Kondelkova, K.; Kunes, P.; Krejsek, J.; Andrys, C. CD200/CD200R paired potent inhibitory molecules regulating immune and inflammatory responses; Part I: CD200/CD200R structure, activation, and function. Acta Med. 2012, 55, 12-17. [CrossRef] [PubMed]

16. Gorczynski, R.; Khatri, I.; Lee, L.; Boudakov, I. An interaction between CD200 and monoclonal antibody agonists to CD200R2 in development of dendritic cells that preferentially induce populations of CD4 ${ }^{+} \mathrm{CD} 25^{+}$T regulatory cells. J. Immunol. 2008, 180, 5946-5955. [CrossRef] [PubMed]

17. Boden, E.K.; Snapper, S.B. Regulatory T cells in inflammatory bowel disease. Curr. Opin. Gastroenterol. 2008, 24, 733-741. [CrossRef] [PubMed]

18. Wang, Y.; Liu, X.P.; Zhao, Z.B.; Chen, J.H.; Yu, C.G. Expression of CD4 ${ }^{+}$forkhead box P3 (FOXP3) ${ }^{+}$ regulatory T cells in inflammatory bowel disease. J. Dig. Dis. 2011, 12, 286-294. [CrossRef] [PubMed] 
19. Ren, Y.; Yang, B.; Yin, Y.; Leng, X.; Jiang, Y.; Zhang, L.; Li, Y.; Li, X.; Zhang, F.; He, W.; et al. Aberrant CD200/CD200R1 expression and its potential role in Th17 cell differentiation, chemotaxis and osteoclastogenesis in rheumatoid arthritis. Rheumatology 2015, 54, 712-721. [CrossRef] [PubMed]

20. Jiang, W.; Su, J.; Zhang, X.; Cheng, X.; Zhou, J.; Shi, R.; Zhang, H. Elevated levels of Th17 cells and Th17-related cytokines are associated with disease activity in patients with inflammatory bowel disease. Inflamm. Res. 2014, 63, 943-950. [CrossRef] [PubMed]

21. Gorczynski, R.M.; Chen, Z.; Lee, L.; Yu, K.; Hu, J. Anti-CD200R ameliorates collagen-induced arthritis in mice. Clin. Immunol. 2002, 104, 256-264. [CrossRef] [PubMed]

22. Meuth, S.G.; Simon, O.J.; Grimm, A.; Melzer, N.; Herrmann, A.M.; Spitzer, P.; Landgraf, P.; Wiendl, H. CNS inflammation and neuronal degeneration is aggravated by impaired CD200-CD200R-mediated macrophage silencing. J. Neuroimmunol. 2008, 194, 62-69. [CrossRef] [PubMed]

23. Zhang, S.; Wang, X.J.; Tian, L.P.; Pan, J.; Lu, G.Q.; Zhang, Y.J.; Ding, J.Q.; Chen, S.D. CD200-CD200R dysfunction exacerbates microglial activation and dopaminergic neurodegeneration in a rat model of Parkinson's disease. J. Neuroinflamm. 2011, 8. [CrossRef] [PubMed]

24. Walker, D.G.; Dalsing-Hernandez, J.E.; Campbell, N.A.; Lue, L.F. Decreased expression of CD200 and CD200 receptor in Alzheimer's disease: A potential mechanism leading to chronic inflammation. Exp. Neurol. 2009, 215, 5-19. [CrossRef] [PubMed]

25. Chakera, A.; Bennett, S.C.; Morteau, O.; Bowness, P.; Luqmani, R.A.; Cornall, R.J. The phenotype of circulating follicular-helper $\mathrm{T}$ cells in patients with rheumatoid arthritis defines CD200 as a potential therapeutic target. Clin. Dev. Immunol. 2012, 2012. [CrossRef] [PubMed]

26. Broderick, C.; Hoek, R.M.; Forrester, J.V.; Liversidge, J.; Sedgwick, J.D.; Dick, A.D. Constitutive retinal CD200 expression regulates resident microglia and activation state of inflammatory cells during experimental autoimmune uveoretinitis. Am. J. Pathol. 2002, 161, 1669-1677. [CrossRef]

27. Li, Y.; Zhao, L.D.; Tong, L.S.; Qian, S.N.; Ren, Y.; Zhang, L.; Ding, X.; Chen, Y.; Wang, Y.X.; Zhang, W.; et al. Aberrant CD200/CD200R1 expression and function in systemic lupus erythematosus contributes to abnormal T-cell responsiveness and dendritic cell activity. Arthritis Res. Ther. 2012, 14. [CrossRef] [PubMed]

28. Akman-Karakas, A.; Yalcin, A.D.; Koc, S.; Gumuslu, S.; Senol, Y.Y.; Ozkesici, B.; Genc, G.E.; Ergun, E.; Ongut, G.; Yilmaz, E.; et al. There might be a role for CD200 in the pathogenesis of autoimmune and inflammatory skin disorders. Med. Sci. Monit. 2013, 19, 888-891. [PubMed]

29. Darmochwal-Kolarz, D.A.; Kludka-Sternik, M.; Chmielewski, T.; Kolarz, B.; Rolinski, J.; Leszczynska-Gorzelak, B.; Oleszczuk, J. The expressions of CD200 and CD200R molecules on myeloid and lymphoid dendritic cells in pre-eclampsia and normal pregnancy. Am. J. Reprod. Immunol. 2012, 67, 474-481. [CrossRef] [PubMed]

30. Banchereau, J.; Steinman, R.M. Dendritic cells and the control of immunity. Nature 1998, 392, $245-252$. [CrossRef] [PubMed]

31. Hubo, M.; Trinschek, B.; Kryczanowsky, F.; Tuettenberg, A.; Steinbrink, K.; Jonuleit, H. Costimulatory molecules on immunogenic versus tolerogenic human dendritic cells. Front. Immunol. 2013, 4. [CrossRef] [PubMed]

32. Jenmalm, M.C.; Cherwinski, H.; Bowman, E.P.; Phillips, J.H.; Sedgwick, J.D. Regulation of myeloid cell function through the CD200 receptor. J. Immunol. 2006, 176, 191-199. [CrossRef] [PubMed]

33. Wu, L.; Liu, Y.J. Development of dendritic-cell lineages. Immunity 2007, 26, 741-750. [CrossRef] [PubMed]

34. Goubier, A.; Dubois, B.; Gheit, H.; Joubert, G.; Villard-Truc, F.; Asselin-Paturel, C.; Trinchieri, G.; Kaiserlian, D. Plasmacytoid dendritic cells mediate oral tolerance. Immunity 2008, 29, 464-475. [CrossRef] [PubMed]

35. Dubois, B.; Joubert, G.; Gomez de Aguero, M.; Gouanvic, M.; Goubier, A.; Kaiserlian, D. Sequential role of plasmacytoid dendritic cells and regulatory T cells in oral tolerance. Gastroenterology 2009, 137, 1019-1028. [CrossRef] [PubMed]

36. Shan, M.; Cheng, H.F.; Song, L.Z.; Roberts, L.; Green, L.; Hacken-Bitar, J.; Huh, J.; Bakaeen, F.; Coxson, H.O.; Storness-Bliss, C.; et al. Lung myeloid dendritic cells coordinately induce TH1 and TH17 responses in human emphysema. Sci. Transl. Med. 2009, 1. [CrossRef] [PubMed]

37. Chappell, C.P.; Giltiay, N.V.; Draves, K.E.; Chen, C.; Hayden-Ledbetter, M.S.; Shlomchik, M.J.; Kaplan, D.H.; Clark, E.A. Targeting antigens through blood dendritic cell antigen 2 on plasmacytoid dendritic cells promotes immunologic tolerance. J. Immunol. 2014, 192, 5789-5801. [CrossRef] [PubMed] 
38. Ito, T.; Yang, M.; Wang, Y.H.; Lande, R.; Gregorio, J.; Perng, O.A.; Qin, X.F.; Liu, Y.J.; Gilliet, M. Plasmacytoid dendritic cells prime IL-10-producing T regulatory cells by inducible costimulator ligand. J. Exp. Med. 2007, 204, 105-115. [CrossRef] [PubMed]

39. Baumgart, D.C.; Thomas, S.; Przesdzing, I.; Metzke, D.; Bielecki, C.; Lehmann, S.M.; Lehnardt, S.; Dorffel, Y.; Sturm, A.; Scheffold, A.; et al. Exaggerated inflammatory response of primary human myeloid dendritic cells to lipopolysaccharide in patients with inflammatory bowel disease. Clin. Exp. Immunol. 2009, 157, 423-436. [CrossRef] [PubMed]

40. Ochando, J.C.; Homma, C.; Yang, Y.; Hidalgo, A.; Garin, A.; Tacke, F.; Angeli, V.; Li, Y.; Boros, P.; Ding, Y.; et al. Alloantigen-presenting plasmacytoid dendritic cells mediate tolerance to vascularized grafts. Nat. Immunol. 2006, 7, 652-662. [CrossRef] [PubMed]

41. Noack, M.; Miossec, P. Th17 and regulatory T cell balance in autoimmune and inflammatory diseases. Autoimmun. Rev. 2014, 13, 668-677. [CrossRef] [PubMed]

42. Eastaff-Leung, N.; Mabarrack, N.; Barbour, A.; Cummins, A.; Barry, S. Foxp3 ${ }^{+}$regulatory T cells, Th17 effector cells, and cytokine environment in inflammatory bowel disease. J. Clin. Immunol. 2010, 30, 80-89. [CrossRef] [PubMed]

43. Zhang, S.; Phillips, J.H. Identification of tyrosine residues crucial for CD200R-mediated inhibition of mast cell activation. J. Leukoc. Biol. 2006, 79, 363-368. [CrossRef] [PubMed]

44. Shiratori, I.; Yamaguchi, M.; Suzukawa, M.; Yamamoto, K.; Lanier, L.L.; Saito, T.; Arase, H. Down-regulation of basophil function by human CD200 and human herpesvirus-8 CD200. J. Immunol. 2005, 175, 4441-4449. [CrossRef] [PubMed]

45. Mukhopadhyay, S.; Plüddemann, A.; Hoe, J.C.; Williams, K.J.; Varin, A.; Makepeace, K.; Aknin, M.-L.; Bowdish, D.M.E.; Smale, S.T.; Barclay, A.N.; et al. Immune inhibitory ligand CD200 induction by TLRs and NLRs limits macrophage activation to protect the host from meningococcal septicemia. Cell Host Microbe 2010, 8, 236-247. [CrossRef] [PubMed]

46. Rosenblum, M.D.; Olasz, E.; Woodliff, J.E.; Johnson, B.D.; Konkol, M.C.; Gerber, K.A.; Orentas, R.J.; Sandford, G.; Truitt, R.L. CD200 is a novel p53-target gene involved in apoptosis-associated immune tolerance. Blood 2004, 103, 2691-2698. [CrossRef] [PubMed]

47. Jurgens, H.A.; Amancherla, K.; Johnson, R.W. Influenza infection induces neuroinflammation, alters hippocampal neuron morphology, and impairs cognition in adult mice. J. Neurosci. 2012, 32, 3958-3968. [CrossRef] [PubMed]

48. Levine, A.; Griffiths, A.; Markowitz, J.; Wilson, D.C.; Turner, D.; Russell, R.K.; Fell, J.; Ruemmele, F.M.; Walters, T.; Sherlock, M.; et al. Pediatric modification of the Montreal classification for inflammatory bowel disease: The Paris classification. Inflamm. Bowel Dis. 2011, 17, 1314-1321. [CrossRef] [PubMed]

49. Schroeder, K.W.; Tremaine, W.J.; Ilstrup, D.M. Coated oral 5-aminosalicylic acid therapy for mildly to moderately active ulcerative colitis. A randomized study. N. Engl. J. Med. 1987, 317, 1625-1629. [CrossRef] [PubMed]

50. Zholudev, A.; Zurakowski, D.; Young, W.; Leichtner, A.; Bousvaros, A. Serologic testing with ANCA, ASCA, and anti-OmpC in children and young adults with Crohn's disease and ulcerative colitis: Diagnostic value and correlation with disease phenotype. Am. J. Gastroenterol. 2004, 99, 2235-2241. [CrossRef] [PubMed]

51. Slukvin, I.I.; Vodyanik, M.A.; Thomson, J.A.; Gumenyuk, M.E.; Choi, K.D. Directed differentiation of human embryonic stem cells into functional dendritic cells through the myeloid pathway. J. Immunol. 2006, 176, 2924-2932.

(C) 2015 by the authors; licensee MDPI, Basel, Switzerland. This article is an open access article distributed under the terms and conditions of the Creative Commons by Attribution (CC-BY) license (http:/ / creativecommons.org/licenses/by/4.0/). 